\title{
First record of the suctorian ciliate Ophryodendron abietinum (Ciliophora, Phyllopharyngea), the epibiont of Hydrozoa in the White Sea
}

\author{
Valeriia Khabibulina ${ }^{1,2}$, Maksim Melekhin ${ }^{3}$, Mariia \\ Belokon ${ }^{4}$ and Nikita Borodin ${ }^{4}$
}

\author{
1 “Centre for Culture Collection of Microorganisms" of Research Park of St. \\ Petersburg State University, St. Petersburg, Russia \\ ${ }^{2}$ Zoological Institute of Russian Academy of Sciences, Core Facilities Centre \\ “Taxon”, St. Petersburg, Russia \\ ${ }^{3}$ Zoological Institute of Russian Academy of Sciences, Laboratory of Cellular and \\ Molecular Protistology, St. Petersburg, Russia \\ ${ }^{4}$ Saint Petersburg State University, Faculty of Biology, St. Petersburg, Russia
}

| Submitted November 20, 2020 | Accepted December 22, 2020|

\begin{abstract}
Summary
The species of the genus Ophryodendron are epibionts of various invertebrate animals. They are rarely found in nature, and very little research has been dedicated to them recently. Ophryodendron abietinum, an epibiont of a hydrozoan Obelia longissima, was discovered in the White Sea for the first time. This study provides a description of O. abietinum life cycle forms and host-epibiont interactions.
\end{abstract}

Key words: ciliates, epibionts, Hydrozoa, Obelia longissima

\section{Introduction}

Suctoria is a subclass of ciliates (Ciliophora, Phyllopharyngea) with peculiar characteristics of the feeding process (suction) and cortex organization when only resettlement forms are ciliated (Bardele, 1970, 1972; Dovgal, 2002; Lynn, 2008). Some species of suctorians are epibionts of various organisms (Fernandez-Leborans et al., 1996, 2002; Dovgal, 2002; Dovgal et al., 2008; Sergeeva et al., 2014). Most epibiotic ciliates have not been studied in detail, and little is known about their biology and diversity. Ophryodendron spp. are an excellent example of the neglected suctorian epibionts whose relationships with their basibionts remain undiscovered.

Ophryodendron abietinum was discovered on the hydrozoan colonies in 1859 (Claparéde and Lachmann, 1859). Further studies on O. abietinum focused only on some aspects of general morphology (Hincks, 1873; Martin, 1909). The authors described the species and provided ideas about its possible life cycle consisting of two life forms: the proboscidiform and the vermiform. However, due to the rare registration of the species, the authors did not provide sufficiently detailed data. Other species of the genus Ophryodendron inhabit a wide range of marine invertebrates, including hydroids (Claparéde and 
Lachmann, 1859; Martin, 1909), crustaceans (Bâtisse and Dragesco, 1967; Bâtisse, 1969; FernandezLeborans et al., 1996, 2002), nemertines (Duboscq, 1925) and polychaetes (Wailes, 1925). During the $20^{\text {th }}$ century, there were no general studies on the genus Ophryodendron, but some authors (Wailes, 1925; Jahn and Jahn, 1949) mentioned particular species. Only at the turn of the century, FernandezLeborans and co-authors published two articles (Fernandez-Leborans et al., 1996, 2002) where they provided the morphological description of $O$. mysidacii and its life cycle. The structure of the genus Ophryodendron and the whole family Ophryodendridae remains doubtful, and more data are required for a proper revision (Jankowski, 1981; Dovgal, 2002). Thus, the present study is the first detailed description of $O$. abietinum after its last discovery at the beginning of the $20^{\text {th }}$ century.

\section{Material and methods}

The study area is situated near the educational and research station "Belomorskaya" of Saint Petersburg State University at Sredniy Island, Chupa Bay, the White Sea, 66 $17^{\prime} 21^{\prime \prime}$ N, 33 39'41" E (Fig. $1)$. The first site of sample collection was located along the shores of the strait between Bolshoy Gorely Island and the mainland, the second site - on the western coast of Vichennaya Luda Island. Both sites were chosen due to the presence of the abundant kelp forests of Laminaria sp. which serves as a substrate for Obelia colonies. The sampling was done during the end of July - beginning of August in 2018-2020.

For the first time, O. abietinum was discovered accidentally on fixed colonies of the hydrozoan Obelia longissima (Pallas, 1766), typical for the White Sea, in 2018 near Bolshoy Gorely Island (Fig. 1, site 1). The colonies were collected and preserved in $4 \%$ paraformaldehyde (PFA) in $0.1 \mathrm{M}$ phosphate-buffered saline (PBS). After fixation, specimens were transferred to PBS solution with $0.1 \% \mathrm{NaN}_{3}$ for conservation. During subsequent light and fluorescent (stained with DAPI) microscopic investigation of Ob. longissima, numerous individuals of $O$. abietinum species were found. However, while in the summer of 2019 we repeatedly found $O$. abietinum at the same collection point, in 2020 we only discovered $O$. abietinum at the western coast of Vichennaya Luda Island (Fig. 1 , site 2).

The samples of the kelp thalli with rhizoids were collected by boat hooking from the depth of
5-10 meters. The kelp pieces with Ob. longissima colonies were cut off for further observation in laboratory conditions. Additionally, colonies of the closely related littoral hydrozoan species, Gonothyraea loveni (Allman, 1859), were collected from the brown algae Ascophyllum nodosum and Fucus vesiculosus at the same sites. The observation of the collected hydrozoan colonies was conducted with Leica EZ4HD stereo microscope (Leica Microsystems GmbH, Germany).

The photographs of the live specimens were taken with Leica DM500 microscope (Leica Microsystems GmbH, Germany) with Samsung Galaxy A3, CMOS $13.0 \mathrm{mp}$ phone camera. The photographs of the nematocysts in cells cytoplasm were taken with Leica TCS SP5 Laser Scanning Confocal Microscope (Leica Microsystems GmbH, Germany), the photographs of fixed cells were taken with Nikon Eclipse Ni equipped with a DS-Fi3 camera (Nikon, Japan). All the morphometric measurements were made using the material fixed in 2018 with FiJi ImageJ program (Babraham Institute, UK). Not less than 10 cells from each morphological form were analyzed.

The cells fixed in 4\% PFA were used for the scanning electron microscopy. The specimens were subsequently dehydrated in series of ethanol solutions and acetone, critically point-dried in Hitachi critical point dryer HCP-2, placed on stubs coated with platinum using Giko IB-5 Ion coater, and viewed under FEI Quanta 250 scanning electron microscope.

\section{Results and discussion}

Systematics (according to Lynn, 2008).

Class Phyllopharyngea de Puytorac et al., 1974

Subclass Suctoria Claparède et Lachmann, 1859

Order Exogenida Collin, 1912

Family Ophryodendridae Stein, 1972

Genus Ophryodendron Claparède et Lachmann, 1859 Ophryodendron abietinum Claparède et Lachmann, 1859

\section{Description}

We found two different stages of $O$. abietinum life cycle (Fig. 2), represented by two distinct forms of cells: proboscidiform and vermiform. We identified both forms as O. abietinum based on general morphological features and hydrozoan host 


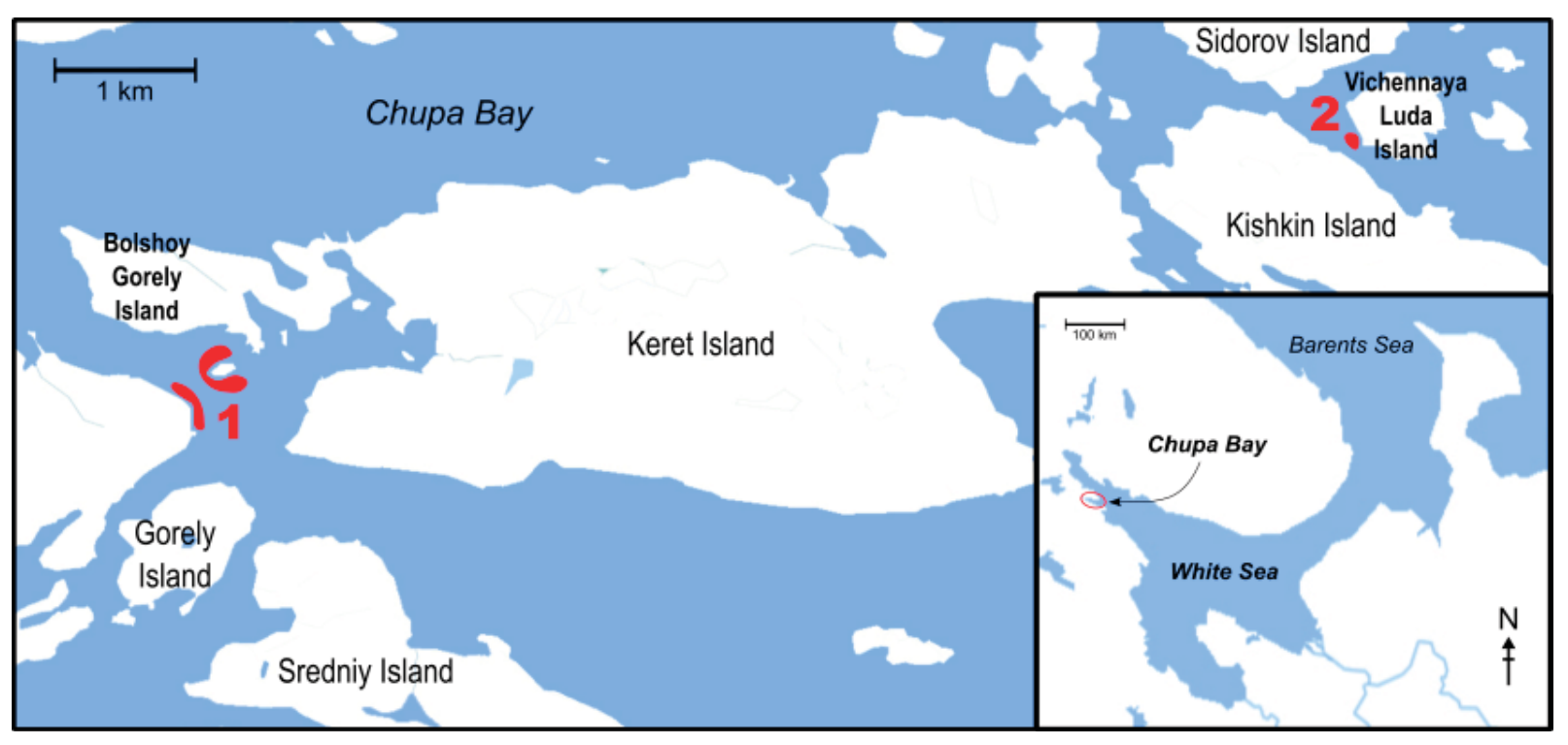

Fig. 1. The map of the sampling points near Sredniy Island, Chupa Bay, the White Sea.

specificity (Claparéde and Lachmann, 1859; Martin, 1909). Furthermore, we discovered the budding cells in fixed material (Fig 2, D) and observed the early stages of budding in living specimens. This finding conveys that both stages belong to the same species.

According to the modern views, proboscidiform and vermiform cells are the stages of the typical suctorian life cycle (Jankowski, 2007; Lynn, 2008). It includes trophont, the attached feeding stage, which forms a short-lived settling swarmer by different types of budding (Dovgal, 2002). In the Ophryodendridae family, trophont is represented by a proboscidiform cell, while swarmer is represented by a vermiform cell. Unlike other suctorian swarmers, which are much smaller than trophonts, the swarmers of Ophryodendron are of the same size as trophonts and do not possess cilia (Jankowski, 2007). They are formed on trophont by vermigemmy, which is considered a variation of exogemmic budding (Dovgal, 2002, 2013).

Trophonts are pear-shaped, $65 \pm 15 \mu \mathrm{m}$ in length and $35 \pm 8 \mu \mathrm{m}$ in width. They possess a feeding apparatus formed by a single actinophore with 2330 tentacles (Fig. 2, B, E). Normally the actinophore stretches out and can reach the edges of the polyp's hydrotheca. In disturbed or fixed specimens, the actinophore contracts forming multiple folds, whereas the tentacles always remain straightened. In a contracted state, the length of the actinophore is $25 \pm 7 \mu \mathrm{m}$. The trophont attaches to the host's perisarc with a basal disk and never forms a stalk.
The basal disk is inconspicuous in live specimens, but it is well distinguishable in fixed cells (Fig. 2, E).

Worm-like swarmers reach $107 \pm 15 \mu \mathrm{m}$ in length and $26 \pm 8 \mu \mathrm{m}$ in width (Fig. 2, C, F). They do not have a feeding apparatus or tentacles. Swarmers always form stalks with a basal disc. Cells can easily detach from these stalks as evidenced by the presence of abandoned stalks on the surface of the perisarc (Fig. 2, F).

\section{Host-epibiont interaction}

Both stages of $O$. abietinum life cycle inhabit the same parts of the Ob. longissima colony. Most of the specimens are typically found in the middle part of the feeding polyp's (gastrozooids) hydrotheca. Less often the cells are located on the thin branches' perisarc near the hydrotheca. We never observed $O$. abietinum on the older parts of the colony which are covered by a thick perisarc layer and on the growing polyps, gonozooids (polyps producing jellyfish), or empty hydrotheca.

The nature of the relationship between $O$. $a b i$ etinum and its host is unclear. Numerous suctorian species, including members of the genus Ophryodendron, are epibionts of a wide range of animals, for example, crustaceans or mites (Fernandez-Leborans and Tato-Porto, 2000, 2002; Chatterjee et al., 2018). Several species inhabit cnidarian colonies or even jellyfish bell surface (Flood et al., 2015). They use the colony's perisarc as a suitable substrate and compete 

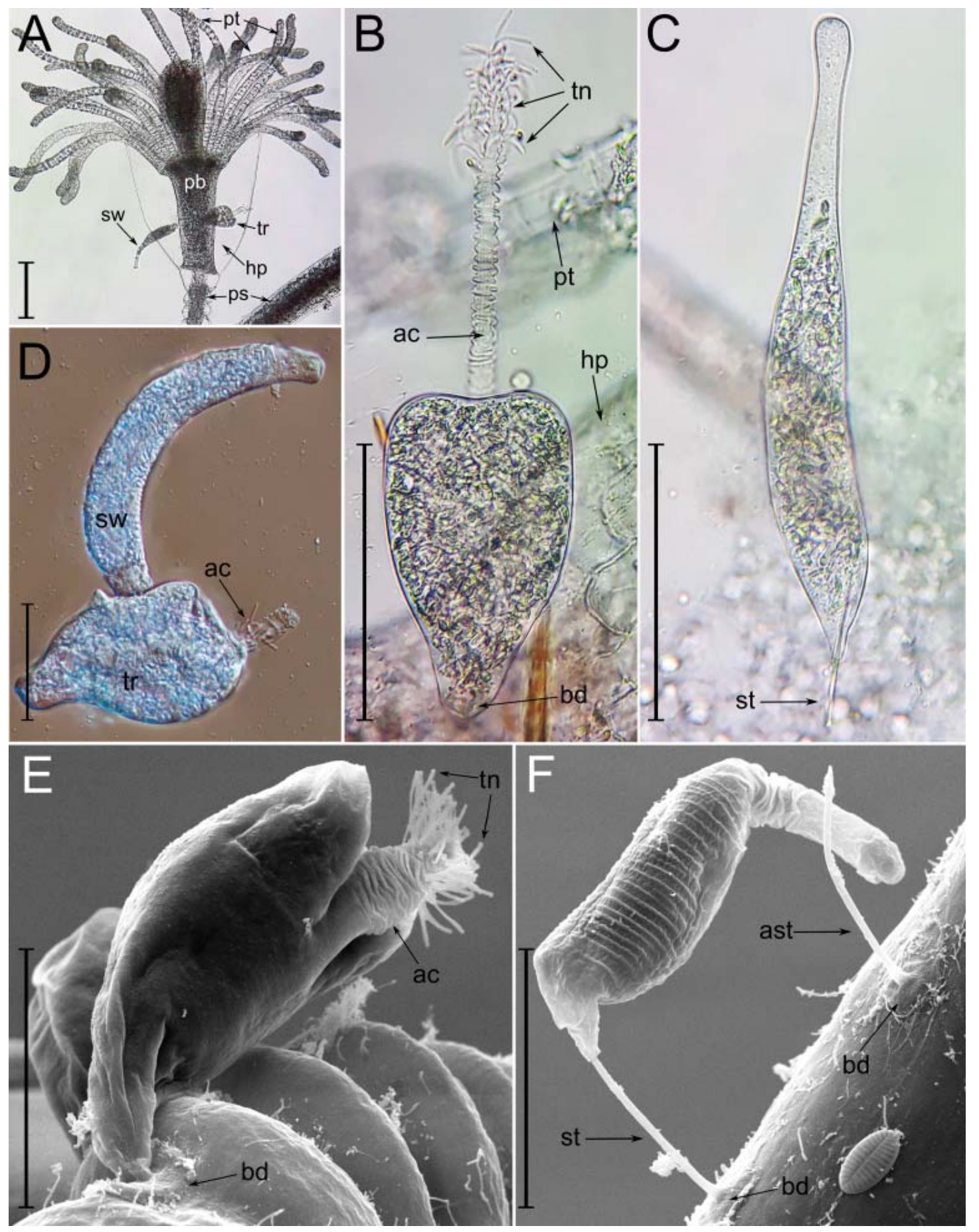

Fig. 2. Different stages of the O. abietinum life cycle. A-C - Live specimens, D - cells fixed in 4\% PFA, E-F - SEM photographs. A - Trophont and swarmer at the hydrotheca of the Ob. longissima feeding zooid, B trophont with elongated actinophore, $\mathrm{C}$ - swarmer. D - vermigemmic budding process, $\mathrm{E}-$ trophont with highly contracted actinophore, $\mathrm{F}-$ swarmer and abandoned stalks at the perisarc of Ob. longissima. Abbreviations: $\mathrm{ac}$ - actinophore, ast - abandoned stalk, bd - basal disk, $\mathrm{hp}$ - hydrotheca of the polyp, $\mathrm{pb}$ - polyp's body, ps - stalks of the polyp's colony, pt - polyp's tentacles, st - stalk, sw- swarmer, tn - tentacles of the actinophore, $\operatorname{tr}-$ trophont. Scale bars: A $-100 \mu \mathrm{m}, \mathrm{B}-\mathrm{F}-50 \mu \mathrm{m}$. 


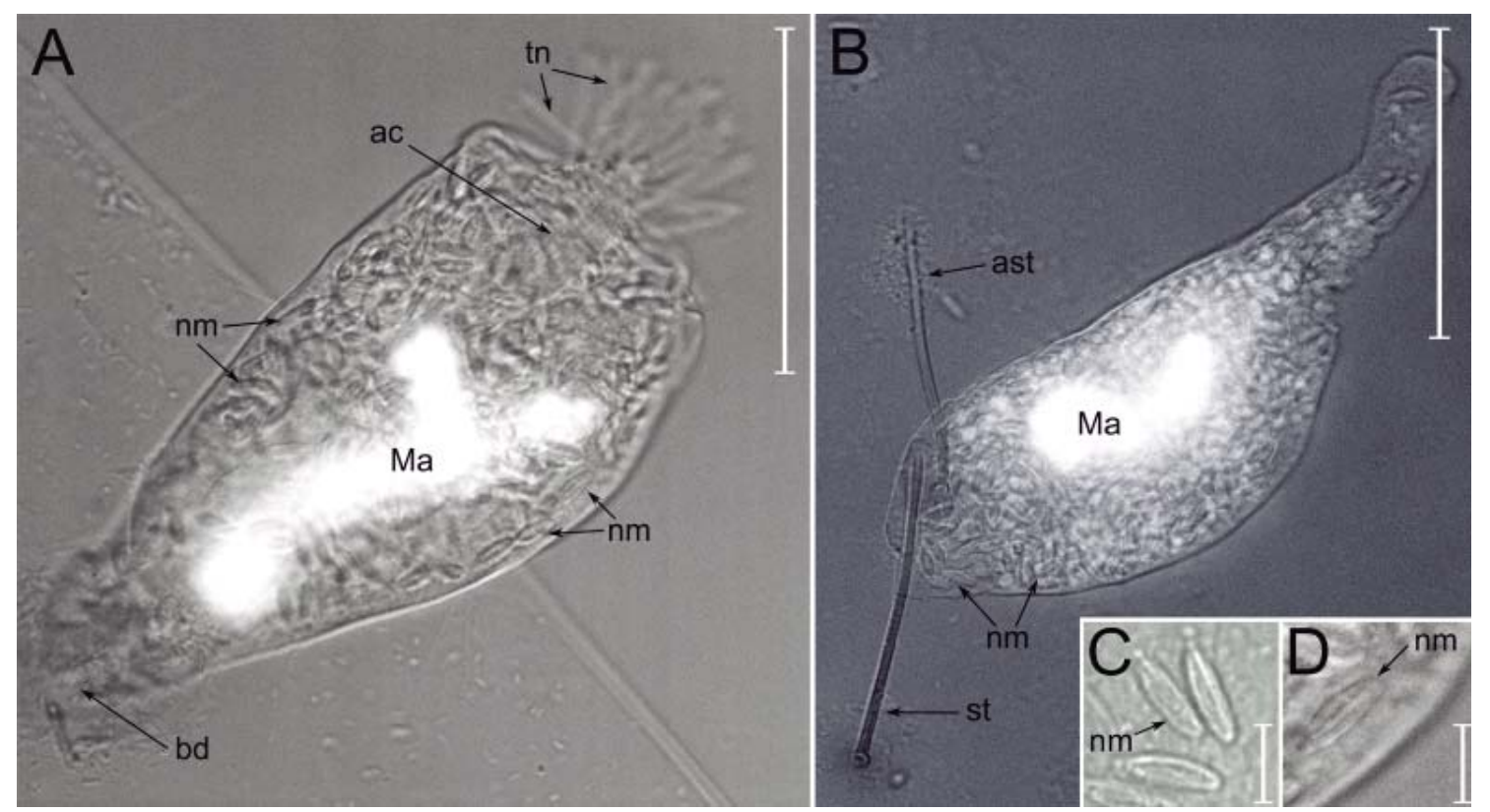

Fig. 3. Nematocyst in cells of different stages of O. abietinum, specimens fixed in $4 \%$ PFA and stained with DAPI. A - Trophont, B - swarmer, C - nematocyst in the tentacle of Ob. longissima, D - nematocysts in the cell of O. abietinum. Abbreviations: Ma - macronucleus, $\mathrm{nm}$ - nematocyst capsule, for explanation of other symbols see Fig. 2. Scale bars: A-B $-50 \mu \mathrm{m}, \mathrm{C}-\mathrm{D}-10 \mu \mathrm{m}$.

for food resources with gastrozooids (Tazioli and Di Camillo, 2013).

O. abietinum and related species were initially considered to be parasites of hydrozoans (Claparède and Lachmann, 1859; Hincks, 1873). This conclusion was based on the presence of multiple nematocysts (stinging capsules of cnidarians), which are particularly well distinguishable in fixed cells (Fig. 3). The unusual feeding process - trophonts absorbing the content from epidermal cells of the cnidarian host tentacles - was observed by Martin $(1909,1914)$. However, trophonts catch prey like other suctorians living on the cnidarian colonies (Tazioli and Di Camillo, 2013). Martin (1909) also mentioned the cases of $O$. abietinum capturing small ciliates. The feeding process of swarmers has not been described, neither in O. abietinum nor in other species of Ophryodendridae. Similar to swarmers of other suctorians, O. abietinum swarmers probably do not feed. Nevertheless, we found nematocysts in all of the observed cells at both stages (Fig. 3). Possibly, swarmers inherit nematocysts from trophonts during budding.

The specificity of the interaction between $O . a b i$ etinum and its host is also uncertain. Historically, O. abietinum was found on various hydrozoan spe- cies: Obelia sp. (Claparède and Lachmann, 1859; Roof, 1922), Clytia sp. (Martin, 1909), Kirchenpaueria pinnata - originally Plumularia pinnata, Halecium halecinum (Hincks, 1873). Detailed descriptions and drawings of $O$. abietinum are absent in most of these works, which date back over a century. Moreover, these hydrozoans live in highly contrasting environmental conditions and have different colony organization, particularly gastrozooids' morphology and arrangement (Antsulevich, 2015).

Over three years, we found $O$. abietinum exclusively on the colonies of Obelia longissima and never observed it on the colonies of Gonothyraea loveni, a closely related species. Ob. longissima and G. loveni are members of the subfamily Obelinae and were previously placed in the genus Obelia due to their high morphological similarity (Bouillon et al., 2004). Both species are abundant in the White Sea but inhabit different ecological niches: Ob. longissima is typically found at the depth of more than five meters in Laminaria sp. kelp forests, whereas G. loveni grows on the brown algae Ascophyllum nodosum and Fucus vesiculosus in the littoral zone. We suppose that the host preference of $O$. abietinum is determined not only by the host morphology but also 
by environmental conditions. In this case, epibiotic ciliates may use hydrozoan species as hosts only if they occupy the appropriate ecological niche.

To conclude, our data show that the two stages of the complex life cycle of the suctorian ciliate $O$. abietinum are regularly found on the colonies of hydrozoan $O b$. longissima in the White Sea. Could this interaction be an example of obligate parasitism accompanied by strong epibiont-host specificity between a suctorian and the hydrozoan, or is it a solely ecological framing? This question is still an enigma, and the actual relationships between O. abietinum and its hydrozoan host remain to be unveiled in the future studies.

\section{Acknowledgements}

The research was carried out at the "Centre for Culture Collection of Microorganisms" of Research Park of St. Petersburg State University as well as the Core Facilities Centre "Taxon" of the Zoological Institute Russian Academy of Sciences, St Petersburg, Russia. We thank Dr. A.A. Dobrovolsky for helping with the first identification of $O$. abietinum and inspiration for this study. This study was supported with the budgetary grant of the Zoological Institute RAS No AAAA-A19119031390116-9.

\section{References}

Antsulevich A.E. 2015. Hydrozoa (Hydroids and Hydromedusae) of Russian Seas. St. Petersburg University Press, Saint Petersburg.

Bardele C.F. 1970. Budding and metamorphosis in Acineta tuberosa. An electron microscopic study on morphogenesis in Suctoria. J. Protozool. 17 (1), $51-70$.

Bardele C.F. 1972. A microtubule model for ingestion and transport in the suctorian tentacle. Z. Zellforch. Microsk. Anat. Histochem. 126 (1), 116-134.

Bâtisse A. 1969. Acinétiens nouveaux ou mal connus des côtes méditerranéennes françaises I. Ophryodendron hollandei n. sp. (Suctorida, Ophryodendridae). Vie et Milieu, pp. 251-278 (in French).

Bâtisse A. and Dragesco J. 1967. Ophryodendron roscoffensis n. sp. Protistologica. 3 (2), 103-112.
Bouillon J., Medel M.D., Pagès F., Gili J.M., Boero F. and Gravili C. 2004. Fauna of the Mediterranean hydrozoa. Scienta Marina, 68 (Suppl. 2), Barcelona.

Chatterjee T., Dovgal I., Pešić V. and Zawal A. 2018. A checklist of epibiont suctorian and peritrich ciliates (Ciliophora) on halacarid and hydrachnid mites (Acari: Halacaridae Hydrachnidia). Zootaxa. 4457 (3), 415-430.

Claparède R. and Lachmann J., 1859. Etudes sur les infusoires et les rhizopodes. Extrait des Mémoires de l'Institut génevois 1, Geneve.

Dovgal I.V. 2002. Evolution, phylogeny and classification of Suctorea (Ciliophora). Protistology. 2 (4), 194-270.

Dovgal I.V. 2013. Fauna of Ukraine.Vol. 36: Ciliates - Ciliophora. Issue 1: Class Suctorea. Naukova Dumka, Kiev (in Russian).

Dovgal I., Chatterjee T. and Ingole B. 2008. An overview of suctorian ciliates (Ciliophora, Suctorea) as epibionts of halacarid mites (Acari, Halacaridae). Zootaxa. 1810, 60-68.

Duboscq O. 1925. Ophryodendron prenanti n. sp. Parasite de cephalothrix linearis rathke. Bull. soc. zool. Fr. 50, 398-401.

Fernandez-Leborans G. and Tato-Porto M.L. 2000. A review of the species of protozoan epibionts on crustaceans. II. Suctorian ciliates. Crustaceana. 73 (10), 1205-1237.

Fernandez-Leborans G. and Tato-Porto M.L. 2002. Distribution of the protozoan epibiont $O p h-$ ryodendron mysidacii (Ciliophora, Suctoria) on the mysid Schistomysis parkeri (Crustacea). J. Nat. Hist. 36 (5), 505-513.

Fernandez-Leborans G., Tato-Porto M.L. and Sorbe J.C. 1996. The morphology and life cycle of Ophryodendron mysidacii sp. nov. a marine suctorian epibiont on a mysid crustacean. J. Zool. 238 (1), 97-112.

Flood P.R., Spriet E., Erichsen E.S. and Dovgal I.V. 2015. First record of a ciliate suctorian (Ciliophora, Suctorea) epibiont on the jellyfish Pelagia noctiluca (Scyphozoa, Semaeostomaeida). Ecol. Montenegrina. 2 (4), 302-306.

Hincks T. 1873. Memoirs: on the protozoon Ophryodendron abietinum, Claparède and Lachmann. J. Cell Sci. 2 (49), 1-9.

Jahn T.L. and Jahn F.F. 1949. How to know the protozoa: a pictured-key for identifying the more common fresh water, marine, and parasitic protozoa, with elementary discussions of the importance 
of each group and of interesting facts concerning them. Dubuque, IA.

Jankowski A.V. 1981. New species, genera and families of tentacled Infusoria (Class Suctoria). Trudy Zoologicheskogo Instituta. 107, 80-115 (in Russian).

Jankowski A.V. 2007. Review of taxa phylum Ciliophora Doflein, 1901. In: Protista: handbook on zoology, Pt.2. (Ed.: Alimov A.F.). Nauka, St. Petersburg, pp. 415-993 (in Russian).

Lynn D. 2008. The ciliated protozoa. Characterisation, classification, and guide to the literature, $3^{\text {rd }}$ Ed. Springer Science and Business Media B.V., Berlin.

Martin C.H. 1909. Some observations on Acinetaria. Part 3-The dimorphism of Ophryodendron. Q. J. Microsc. Sci. 53, 629-664.

Martin C.H. 1914. A note on the occurrence of nematocysts and similar structures in the various groups of Animal Kingdom. Biol. Zent. B1. 34, 248-434.

Roof F.M. 1922. A new suctorian from Woods Hall. Trans. Am. Microsc. Soc. 41 (2), 77-81.

Sergeeva N. and Dovgal I. 2014. First finding of epibiont peritrich and suctorian ciliates (Ciliophora) on oligochaetes and harpacticoid copepods from the deep-water hypoxic/anoxic conditions of the Black Sea. Ecol. Montenegrina. 1 (1), 49-54.

Tazioli S. and Di Camillo C.G. 2013. Ecological and morphological characteristics of Ephelota gemmipara (Ciliophora, Suctoria), epibiontic on Eudendrium racemosum (Cnidaria, Hydrozoa) from the Adriatic Sea. Eur. J. Protistol. 49 (4), 590-599.

Wailes G.H. 1925. Some new or rare protozoa from British Columbia. J. Nat. Hist. 16 (91), 40-48.

Address for correspondence: Maksim Melekhin. Zoological Institute of Russian Academy of Sciences, Universitetskaya emb.7/9, 199034 St. Petersburg, Russia; e-mail: maksim.s.melekhin@gmail.com 